\title{
Colorectal Cancer pN2b TNM Finding v8
}

National Cancer Institute

\section{Source}

National Cancer Institute. Colorectal Cancer pN2b TNM Finding v8. NCI Thesaurus. Code C134179.

Colorectal cancer in which seven or more regional lymph nodes are positive. (from AJCC 8th Ed.) 